ISSN : 2087-2461

PENANGGUNG JAWAB Dekan FIKOM

Evie Sofiati MI, M.I.Kom

Sekretaris Dekan

Dian Marhaeni K, M.Si

Ketua Penyunting

Made Dwi Adnjani, M.Si

Sekretaris

Mubarok, M.Si

Bendahara

Parwati, SH

Dewan Penyunting

Trimanah, M.Si

Edi Ismoyo, M.Si

Suharyoso, S.Sos

Seksi Usaha

Endang Winarsih, S.Sos

Sirkulasi dan Distribusi

Aldino Leoniv, ST

Alamat Redaksi

Fakultas Ilmu Komunikasi

Universitas Islam

Sultan Agung Semarang

J1. Raya Kaligawe Km. 4

Po. Box 1054/SM

Semarang 50112

Telp. (024) 6583584

ext. $448 / 449$

Fax. (024) 6582455

email : jurnalfikom@yahoo.com
Pengaruh Perubahan Nama Terhadap Citra Pada Telkom

University

Felesia Ekafaya Kirianawati, Roro Retno Wulan,

Kharisma Nasionalita

felesiaekafay@gmail.com

Komunikasi Lintas Budaya Etnis India, Etnis China serta

Pribumi di kampung Lubuk Pakam

Meilani Dhamayanti

mdhamayanti73@gmail.com

Analisis Komunikasi Pemasaran Melalui Strategi Brand Activation Pond's Untuk Meraih Top Brand Award 2013 Rustono Farady Marta ${ }^{1}$, Pricillia ${ }^{2}$, Maria Fransisca Kosasih ${ }^{3}$, Maria Christina Evelyn Iskandar ${ }^{4}$

rustonofarady@gmail.com ${ }^{1}$, icil_22@hotmail.com ${ }^{2}$, s43_s43@yahoo.com ${ }^{3}$,

mariachristinaevelyne@gmail.com ${ }^{4}$

Analisis Isi Visual Iklan Dan Strategi Kreatif Kategori Print Ad Pemenang Gold, Silver, dan Bronze Citra Pariwara 2015

Dina Nur Handayani ${ }^{1}$ (dinurhdyn@gmail.com)

Ratih Hasanah Sudrajat ${ }^{2}$ (kumaharatih@gmail.com ${ }^{2)}$

Ayub Ilfandy Imran ${ }^{3}$ (a_ilfandy@yahoo.com ${ }^{3}$ )

Refleksi Citra Indonesia Sebagai Dampak Politik Migrasi TKI

ke Malaysia

Mutia Rahmi Pratiwi (mutiarahmipratiwi@gmail.com)

Amida Yusriana (amidayusriana88@gmail.com)

$46-59$

Karakteristik Press Release Praktisi Public Relations Hotel di Yogyakarta

Margaretha Sonya, Meylani Yo, Nobertus Ribut Santoso

margaretha_sonyalee@yahoo.com

$60-70$

Isu LGBT dalam Bingkai Media Online

Muhammad Ghifari Putra ${ }^{1}{ }^{1}$ ghifarigp@gmail.com)

Kharisma Nasionalita ${ }^{2}$

${ }^{2}$ nasionalita.kharisma@gmail.com

$71-87$

Telepon Selular dan Ruang Publik : Representasi Identitas Siswantini

yjuliman@gmail.com

$88-94$

Kepemilikan dan Bingkai Media (Analisis Framing Pemberitaan Joko Widodo Sebagai Kandidat Calon Presiden pada Koran SINDO)

Nani Kurniasaril (nani.kurniasari@kalbis.ac.id ${ }^{1}$ )

Gilang GustiAji² (gilangaji@unesa.ac.id²)

$96-116$ 


\title{
TELEPON SELULAR dan RUANG PUBLIK: REPRESENTASI IDENTITAS
}

\author{
Oleh : \\ Siswantini \\ yjuliman@gmail.com \\ Faculty Member of Marketing Communicaiton, Fakultas Bisnis dan Marketing Komunikasi, \\ Universitas Bina Nusantara, Jakarta
}

\begin{abstract}
Cell phone, or better known as a hand-phone today has become a primary need of the owner. Indonesia with a large population is also the country with the largest number of phone users. A mobile phone as a communication tool has made people able to communicate regardless oftime and space. The article is intended to provide an overview of the representation of the identity of its users in public spaces. The study was conducted by conducting a short study on the use of mobile phones on public transport
\end{abstract}

Keywords : mobile phones, representation of identity, public space

\begin{abstract}
Abstrak
Telepon genggam atau lebih dikenal dengan hand-phone dewasa ini sudah menjadi kebutuhan primer dari pemiliknya. Indonesia dengan jumlah penduduk yang besar juga merupakan Negara dengan jumlah pengguna telepon terbesar. Telepon genggam sebagai alat komunikasi telah menjadikan orang dapat melakukan komunikasi tanpa mengenal ruang dan waktu. Artikel ditujukan untuk memberikan gambaran tentang representasi identitas para penggunanya di ruang public. Kajian dilakukan dengan melakukan penelitian singkat terhadap penggunaan telepon genggam di kendaraan umum
\end{abstract}

Kata kunci: telepon genggam, representasi identitas, ruang publik

\section{Latar Belakang}

Indonesia merupakan pasar potensial penjualan telepon selular (hand-phone) bagi para produsennya. Data dari Wireless Inteligence menunjukkan bahwa Indonesia merupakan negara ke 5 terbesar jumlah pengguna telepon genggamnya. Saat ini pengguna telepon selular di Indonesia diperkirakan sebesar 250 juta, sedangkan penduduk Indonesia berjumlah 238 juta, artinya di Indonesia terdapat banyak individu yang memiliki lebih dari satu buah telepon selular. Kehadiran telepon selular pada akhirnya telah merubah perilaku sosial penggunanya.

Berbagai penelitian yang telah dilakukan menunjukkan bahwa telepon selular dimaknai oleh pemiliknya dengan berbagai cara diantaranya untuk menunjukan luasnya jaringan pertemanan (Campell dan Kelley, 2006; Johnsen, 2003; Licoppe, 2003; Ling dan Yttri, 1999, 2002; Plant 2001; Taylor dan Harper, 2001), sebagai pelengkap penampilan (Gant dan Kiesler, 2001; Hulme dan Peters, 2001; Oksman dan Rautiainen, 2003) dan juga merupakan simbol dari identitas (Campbell, 2008; Campbell dan Russo, 2003; Green, 2003; Katz dan Sugiyama, 2006; Ling, 2003; Ling dan Yttri, 1999, 2002; Lobet-Maris, 2003; Skog, 2002; Strocchi, 2003; Taylor dan Harper, 2001). Faktor sosial lain yang berkaitan dengan penggunaan telepon selular adalah penggunaan telepon di ruang publik. 
Artikel ini terinspirasi oleh hasil penelitian Campbell (2003) yang meneliti tentang persepsi antar budaya tentang penggunaan telepon selular di ruang public. Hasil penelitian yang melibatkan responden dari Amerika Serikat, Hawaii, Taiwan, Jepang dan Swedia, menunjukkan bahwa masing-masing negara memiliki persepsi yang berbeda tentang penggunaan telepon selular di tempat umum. Penulis sendiri tetarik untuk mengamati bagaimana penggunaan telepon genggam orang Indonesia di ruang publik. Hal ini menarik karena Indonesia selain penduduknya banyak, juga memiliki suku bangsa yang sangat beragam, dan masing-masing suku memiliki budaya yang berbeda-beda juga. Keragaman budaya itupun menghiasi keragaman dalam menggunakan telepon genggam sebagai alat komunikasi. Dalam pengamatan ini penulis focus pada penggunaan telepon selular untuk komunikasi secara verbal.

Di Indonesia, saat ini telepon selular dimiliki oleh semua lapisan masyarakat mulai dari pejabat tinggi negara, pengusaha, sampai dengan pemulung, mulai dari orang lanjut usia, remaja hingga anak-anak. Dari beragam profesi dan usia ini bisa dipastikan, saat ini akan lebih sulit menemukan orang Indonesia yang tidak memiliki telepon selular dibandingkan dengan orang yang memilikinya. Kalaupun kita tidak memilikinya atau tidak membawanya, keseharian kita akan dilingkupi oleh orang-orang yang menggunakan telepon. Telepon selular dengan bebas dapat digunakan dimana saja, kapan saja dan dalam situasi apa saja.

\section{Rumusan Masalah}

Penggunaan telepon seluler di tempat umum atau ruang publik tidak semuanya diterima oleh masyarakat secara umum. Penggunaan telepon umum ini juga terkait dengan budaya suatu masyarakat. Rumusan masalah dalam penelitian ini adalah: "Bagaimana representasi identitas pengguna telepon genggam di ruang publik?"

\section{Tujuan Penelitian}

Penelitian kecil ini dimaksudkan untuk turut melengkapi penelitian yang telah dilakukan oleh Campbell tentang persepsi penggunaan telepon selular di tempat umum, melalui perbandingan dari berbagai budaya dari negara-negara yang berbeda dengan mengembangkan penelitian pada kelompok yang lebih spesifik di Indonesia. Tujuan yang ingin dicapai dari penelitian ini adalah menggambarkan representasi latar belakang budaya pengguna telepon genggam di ruang publik. Informan dalam penelitian kecil ini berasal dari budaya sunda, Jawa, Batak dan Melayu, dengan latar belakang pendidikan dan pekerjaan yang berbeda-beda.

\section{Metapora Dramaturgi dari Erving Goff- man's}

Telepon selular sebagai alat komunikasi memiliki karakteristik yang kompleks, Tidak adanya ketentuan yang baku dalam penggunaan handphone menjadikan kita dapat melakukan percakapan melalui telepon dimana saja kita berada. Menurut apa yang telah dilakukan Campbell (2007), pendekatan dramaturgi tentang interaksi sosial dapat digunakan untuk mengamati fenomena penggunaan telepon selular di tempat umum, khususnya kendaraan umum. Pendapat ini senada dengan penelitian yang sudah dilakukan oleh Fortunati (2003); Humpreys, 2005; Ling, 2002; 2004).

Menurut Goffman (1959) individu menampilkan dirinya seperti berada di atas panggung ketika berinteraksi dengan orang lain, seperti sebuah panggung pertunjukan, panggung sosialpun terdiri dari area depan dan area belakang. Panggung depan merujuk pada penampilan fisik dan sosial dimana peristiwa itu terjadi, sementara panggung belakang merujuk pada perilaku-perilaku dan informasi yang disembunyikan dari orang lain untuk menciptakan kesan tertentu (impression management). Kompetensi menampilkan panggung depan terlihat dari kemampuannya menyembunyikan hal-hal ingin disembunyikan di panggung belakang (Fortunati, 2003). 
Dalam penggunaan telepon selular di tempat umum, individu penggunanya harus mampu menampilkan dua panggung yang berbeda pada saat yang bersamaan, terkait dengan keberadaannya di depan orang lain yang berada di sekitarnya dan orang yang sedang berbicara dengannya di telepon (Ling, 2002). Panggung depan dan panggung belakang ini keduanya terkait dengan norma-norma tertentu (Humphreys, 2005; Love dan Kewley, 2003; Palen, Salzman, dan Youngs, 2001)

Dalam bukunya "Behavior in Public Place”, Gofmann (1966;36) menjelaskan bahwa penampilan panggung depan seseorang tergantung pada tingkat keterlibatan atau tingkat perhatian yang diberikan untuk memperoleh perhatian kognitif dan afektif terhadap suatu peristiwa, atau dengan kata lain sejauh mana seseorang terlibat dalam suatu suasana tertentu. Keterlibatan seseorag dalam suatu situasi sosial bermacam-macam tergantung peristiwa sosial yang dihadapinya. Dalam suasana fully focused gathering, setiap orang yang hadir diharapkan terlibat penuh dalam aktivitas yang berlangung, misalnya di ruang belajar atau pelatihan. Dalam partially-focused gathering, hanya sebagian partisipan saja yang terlibat, yang lainnya tidak memperhatikan atau bahkan tidak peduli. Sedangkan dalam multifocused gathering, hanya satu atau lebih partisipan saja yang terlibat dalam kegiatan yang sama.

Dalam pertemuan yang membutuhkan perhatian penuh, karena menuntut semua partisipan atau peserta yang hadir terlibat secara penuh, biasa penggunaan telepon selular tidak diperkenankan, dibandingkan pada pertemuan yang tidak terlalu membutuhkan perhatian penuh dari seluruh peserta. Hasil penelitian Haddon (1998) misalnya menemukan bahwa pada acara-acara pertunjukkan, responden lebih memilih untuk menggunakan head-set saat menggunakan telepon. Senada dengan Haddon, penelitian yang dilakukan oleh Wei dan Leung (1999) menemukan bahwa responden merasa tertanggu bila ada orang lain yang menggunakan telepon di gereja, ruang kelas dan restoran, tetapi mereka lebih bertoleransi bila penggunaan telepon selular itu dilakukan di kendaraan umum, jalanan atau pusat perbelanjaan. Caporeal dan Xie (2003) menemukan bahwa responden dalam penelitiannya akan mematikan atau menghidupkan mode getar (silent) jika berada di bioskop, ruang konser, gereja dan dalam rapat, sedangkan Campbell dan Russo (2003) menemukan bahwa respondennya merasa terganggu oleh penggunaan telepon selular di ruang kelas atau bioskop. Penelitian Campbell (2006) lainnya menemukan bahwa sampel dosen dan mahasiswa berpendapat bahwa pelarangan penggunaan telepon seluler di ruang kelas sebaiknya dijadikan peraturan baku.

Berbagai temuan dari beragam penelitian ini menunjukkan bahwa apa yang dikemukakan oleh Goffman pada suasana yang membutuhkan perhatian penuh maka penggunaan telepon genggam lebih tidak ditolelir dibanding dengan suasana yang lebih individual. Menurut Campbell (2007) penting untuk melihat bagaimana praktek-praktek dan harapan-harapan terhadap perilaku di ruang umum dicermati dalam konteks budaya. Seperti dikemukakan oleh Goffman (1966: 45-

46) bahwa "the idiom of subordinate involvements differ widely from one cultural group to another". Sementara Edward Hall's (1965) dalam membahas teori prosemik mengemukakan bahwa budaya memiliki peranan penting dalam membentuk persepsi individu dan penggunaan ruang sosial.

\section{Social Construction of Technology - Trevor Pinch dan Wiebe Bijker}

Riset lain tentang penggunaan telepon selular dilakukan oleh Okabe dan Ito (2005). Penelitiannya berfokus memberikan kontribusi yang cukup signifikan terhadap normanorma penggunaan telepon selular di kendaraan umum di Jepang. Penelitian ini dilakukan metode etnografi dengan wawancara mendalam dan observasi, serta mengembangkan sejarah-sosial. Hasil penelitian Okabe dan Ito tentang telepon selular (keitai) menunjukkan bahwa terjadi transisi dari alat bisnis menjadi teknologi untuk kepentingan sosial. 
Di Jepang, panggilan telepon di dalam kereta atau bis dilarang, kontrol terhadap panggilan telepon ini dilakukan secara formal dan informal, termasuk melalui pengumanpengumuman verbal dan poster yang mengingatkan penumpang tentang larangan tersebut melalui peringatan non-verbal sesama penumpang. Remaja di Jepang di anggap memiliki peranan penting dalam mensosialisasikan kesepakatan ini seiring dengan semakin meningkatnya penggunaan teknologi ini oleh remaja dalam berhubungan dengan sesamanya.

Perkembangan penggunaan internet melalui telepon selular juga mendorong semakin meningkatnya penggunaan email melaui telepon dan menjadi pilihan alternative dibandingkan penggunaan telepon itu sendiri. Singkatnya hasil penelitian Ito dan Okabe tersebut menunjukkan bahwa menerima dan mengirim pesan saat berada di kelas itu lebih dapat diterima dibandingkan dengan panggilan telepon.

Dalam penelitiannya, Okabe dan Ito menggunakan teori social construction of technology (SCOT) yang dikembangkan oleh Pinch dan Bijker. Teori ini menggambarkan tentang bagaimana actor-aktor sosial, faktor sejarha dan konteks sosial menilai sebuah perkembangan, adapatasi dan penggunaan teknologi. Campbell dan Russo (2003) mengadopsi teori yang sama untuk melihat bagaimana berbagai macam persepsi dan penggunaan telepon selular dikuatkan dengan jaringan komunikasi seseorang. Dilakukan dengan pendekatan data kualitatif dan kuantitatif kedua peneliti menemukan bahwa adaptasi, konseptualiasi dan penggunaan telepon selular mempengaruhi oleh interaksi dalam penggunaan telpon tersebut. Dengan kata lain dalam penggunaan telepon, individu tersebut sangat tergantung pada bagaimana dia memandang telepon tersebut. Campbell dan Russo (2003) juga menggambarkan bagimana persepsi dan penggunaan telepon selular, Okabe dan Ito (2005) menggambarkan bagaimana konstruksi sosial atas teknologi muncul pada tingkat budaya yang lebih besar.

Penelitian kecil ini menggunakan teori konstruksi sosial atas teknologi karena ingin menggali kemungkinan perbedaan persepsi pada budaya yang berbeda tentang penggunaan telepon di tempat umum. Karena teknologi di konstruksi secara sosial, maka bisa jadi persepsi terhadap teknologi ini dipengaruhi oleh latar belakang budaya seseorng. Penelitian lain yang dilakukan oleh Katz dan Aakhus (2002) tentang penggunaan telepon selular yang banyak digunakan oleh remaja telah merubah pandangan tentang otonomi dan privasi serta antisipasi terhadap konsekuensi kehadiran teknologi. Hal yang paling relevan dari teori ini adalah bahwa dengan penggunaan telepon selular, orang bisa serta merta merubah ruang public menjadi ruang pribadinya.

Katz dan Aakhus (2002), menyebutkan bahwa trend komunikasi antar budaya dengan menggunakan telepon selular ini sebagai Appartgeist, yang secara harfiah artinya "spirit dari mesin". Secara teori konsep ini berkaitan dengan bagaimana pendapat tentang komunikasi, dimana pada umumnya komunikasi berarti interaksi sosial merupakan kebutuhan dasar manusia Kehadiran telepon selular telah mengubah para penggunannya dalam menilai, menemukan dan menggunakan teknologi komunikasi, yang pada akhirnya menciptakan pola dan trend yang hampir sama di seluruh dunia. Keinginan untuk saling terhubung secara terus menerus secara eksplisit dan implisit terjadi atas dorongan faktor sosial dan teknologi. Contohnya faktor-faktor sosial yang berperan ada nilai, aturan dan normar sedangkan faktor-faktor teknologi adalah segala sesuatu yang dimiliki oleh telepon selular itu sendiri, seperti fitur, ukuran, design dan kemudahan dalam menggunakan.

Singkatnya dengan menggunakan teori social construction of technology, kita dapat melihat bagaimana keterkaitan antara faktorfaktor sosial dengan konstruksi seseorang terhadap teknologi yang digunakannya. Cara pandangitu jugaberkaitan dengan budaya dimana teknologi tersebut digunakan. Dalam penelitian ini, teori SCOT akan dipergunakan untuk menganalisis bagaimana budaya mempengaruhi penggunaan telepon selular pada individunya. 


\section{Metode Penelitian}

Makalah ini merupakan bagian dari hasil penelitian dengan menggunakan metode penelitian etnografi komunikasi, yaitu sebuah penelitian yang mengamati perilaku komunikasi dalam konteks sosial kultural. Data dalam penelitian ini diperoleh dengan melakukan pengamatan terhadap peristiwa-peristiwa komunikasi yang terjadi pada kelompok budaya sunda, jawa, padang dan batak. Peristiwa komunikasi yang diamati adalah komunikasi yang dilakukan dengan menggunakan telepon selular di kendaraan umum.

Unit yang diteliti dalam penelitian ini adalah situasi komunikatif atau konteks terjadinya komunikasi; peristiwa komunikatif dan tindak komunikatif ketika melakukan komunikasi melalui telepon selular.

\section{Penggunaan Telepon Selular di Indonesia}

Pada latar belakang telah dipaparkan bahwa di Indonesia telepon selular dimiliki hampir oleh seluruh kalangan masyarakat, tanpa mengenal batasan status sosial. Jenis dan merk telepon selular yang masuk ke Indonesiapun semakin hari semakin beragam, setiap jenis dan merk memiliki pasarnya masing-masing. Telepon selular pada akhirnya bukan hanya difungsikan sebagai alat untuk berkomunikasi, tetapi memiliki fungsi sosial lainnya, yakni sebagai identitas kelas. Fungsi ini dilihat dari pola pembelian telepon selular oleh masyarakat Indonesia, setiap kelas sosial memiliki brand teleponnya sendiri. Kategori ini dapat diklasifikasikan dari harga teleponselular ituu sendiri.

Kelompok menengah atas, umumnya akan membeli telepon selular dengan harga di atas 3 juta rupiah dengan merk-merk yang ternama seperti Apple, Samsung, Sonny, HTC atau Blackberry. Kelompok ini umumnya sangat memperhatikan dari negara mana produsen teleponnya. Kelompok menengah umumnya membeli telepon selular dengan harga di antara 1 juta - 6 juta rupiah, dan kelompok bawah akan membeli telepon selular di bawah 1 jt rupiah, dan umumnya kelompok ini tidak terlalu memperhatikan merk apa yang dibelinya, tetapi bagaiman memfungsikannya. Sementara pada kalangan menengah atas, walaupun mereka membeli telepon selular dengan harga mahal dan fitur yang beragam, tetapi tidak semua fitur-fitur yang tersedia digunakan.

Secara keseluruhan, setiap kelompok sosial bila dilihat pemakaiannya, pada umumnya pengguna telepon selular ini lebih banyak menggunakan teleponnya untuk berkomunikasi secara verbal dibandingkan dengan pemanfaatan fitur lainnya. Dengan memiliki telepon selular, setiap individu kini dapat berhubungan dengan keluarga, kenalan atau rekan kerjanya dimanapun mereka berada. Telepon seluler ini menjadikan orang-orang dalam jaringan sosial yang sama akan dapat terus terhubung tanpa terbatas ruang dan waktu. Kondisi ini memungkinkan pemilik telepon selular untuk melakukan pemanggilan atau penerimaan telepon dimana saja, termasuk di kendaraan umum.

Tidak ada pengaturan penggunaan telepon di tempat umum atau ruang public secara baku. Pengturan tentang penggunaan telepon selular umumnya hanya dilakukan diruangruang privat seperti kelas, acara diskusi atau seminar dan ditempat yang memungkinkan dampak dari penggunaan handphone tersebut akan mengganggu alat elektronik lain seperti di pompa bensin atau pesawat terbang.

Aturan baku tentang penggunaan telepon selular hanya ada saat kita ber-kendaraan, tentang hal itu telah diatur dalam UU no. 22 tahun 2009 tentang Lalulintas dan Angkutan Jalan. Pasal 283, menyebutkan bahwa "setiap orang yang mengemudikan kendaraan bermotor di jalan secara tidak wajar dan melakukan kegiatan lain atau dipengaruhi oleh keadaan yang mengakibatkan gangguan konsentrasi dalam mengemudi dijalan, ...dipidana dengan pidana kurungan paling lama 3 bulan atau denda paling banyak Rp. 750,000, (tujuh ratus lima puluh ribu rupiah". Gangguan konsentrasi dalam berkendaraan dalam peraturan ini termasuk penggunaan telepon selular.

Kompleksitas penggunaan telepon selular juga berkaitan dengan norma-norma so- 
sial dan budaya, khususnya penggunaannya diruang publik. Salah satu penggunaan akibat dari penggunaan telepon selular di tengah keramaian menjadikan penggunanya seolaholah "mengilang" dari kerumunan atau keramaian dimana dia berada. Salah satu adalah penggunaan telepon selular di dalam kendaraan umum.

Saat berada di kendaraan umum, orang yang melakukan percakapan melalui telepon selular, seringkali lupa bahwa dia berada di tengah orang asing yang tidak mengenalnya. Tanpa disadari penelpon, ia sudah menjadikan telepon genggam itu sebagai ruang publiknya. Tanpa sungkan penerima telpon akan berbicara tentang hal-hal yang bersifat pribadi antara dirinya dan penelpon. Ia tidak menyadari bahwa hal-hal yang bersifat pribadi tersebut terdengar oleh orang lain yang berada disekitarnya.

Pengamatan penulis pada beberapa kasus percakapan handhpone di ruang public menyangkut berbagai hal, dan juga menyangkut berbagai karakter penggunanya. Dari pengamatan tersebut diperoleh gambaran bahwa penggunaan telepon selular di ruang public juga berkaitan dengan usia, profesi dan asal daerah. Penggunaan bahasa ketika berbicarapun dominannya dipengaruhi oleh tiga unsur tersebut. Orang-orang dengan usia lebih muda seperti anak-anak dan pelajar akan menggunakan bahasa yang lebih sederhana dan cenderung membicarakan hal-hal yang sederhana. Kelompok usia yang lebih tua akan melakukan pembicaraan yang lebih kompleks dengan durasi pembicaraan yang lebih lama.

Profesi juga membedakan cara orang menerima telepon di ruang public, orang dengan yang berkerja di perusahaan tertentu ("kantoran") berbeda dengan orang yang berprofesi sebagai pedagang. Bahasa yang digunakan oleh orang-orang yang bekerja di tempat-tempat yang membutuhkan suasana formal, seringkali berbicara dengan bahasa formal jika berbicara dengan rekannya, dan cenderung berbicara secara singkat dengan suara yang lebih pelan jika berbicara masalah pribadi dengan teman dekat atau keluarga.
Sementara pada orang-orang dengan profesi pedagang (skala kecil), buruh, kuli dan pekerjaan lain yang terindikasi tidak membutuhkan pendidikan tinggi, berbicara dengan bahasa non formal, lebih sering menggunakan bahasa daerah dan bersuara dengan lantang/keras.

Temuan lapangan tersebut, terlihat bahwa pada saat melakukan pembicaraan melalui telepon selular pada kelompok pekerja rendahan seperti pedagang, mereka umumnya tidak melakukan pengelolaan kesan yang berlebihan, mereka cenderung natural dan tidak tampak berbeda dengan perilaku komunikasi sehari-harinya.. Pengelolaan panggung depan yang terlihat dari kata-kata yang digunakan terutama saat berhubungan dengan orang-orang terdekat, seperti keluarga atau teman-teman dalam jaringannya. Pernyataanpernyataan yang digunakan baik yang bersifat pertanyaan, pengarahan maupun pernyataannya sangat lugas.

Pemilihan kata-kata, pernyataan dan gerak non verbal yang ditampilkan saat melakukan percakapan melalui telepon selular, ditunjukkan dengan sangat berbeda pada kelas sosial yang lebih tinggi. Umumnya pada kelas sosial yang lebih tinggi, ketika melakukan pembicaraan melalui telepon selular, mereka melakukannya seperti mereka bertatap muka, tetap melakukan pengelolaan kesan. Pengelolaan kesan itu dilakukan melalui pemilihan kata, pernyataan maupun pertanyaan.

Kecanggihan teknologi saat ini memungkinkan telepon selular bukan hanya dipergunakan sebagai alat komunikasi verbal (berbicara) tetapi juga untuk berkirim teks, dan gambar (foto dan video). Walaupun saat ini orang berlomba-lomba untuk memiliki telepon genggam dengan fasilitas yang paling canggih, tetapi pada prakteknya hanya sedikit dari pemilik telepon selular canggih itu yang memanfaatkan fasilitasnya, umunya penggunaan tetap lebih banyak pada penggunaan telepon dan pengiriman pesan singkat (short message service/sms) saja.

Gambaran penggunaan telepon ini menunjukkan bahwa seseorang ketika menggunakan telepon, mengkonstuksi penggu- 
naannya sesuai dengan latar belakang budayanya atau kelas sosialnya. Telepon sebagai alat komunikasi hasil perkembangan teknologi dikonstruksi oleh penggunanya sesuai dengan kebutuhan sosialnya, termasuk dalam mentransformasi ruang public menjadi ruang pribadi penggunanya.

\section{Kesimpulan}

Dari pengamatan singkat tentang penggunaan telepon di tempat umum tersebut dapat diambil kesimpulan bahwa ketika melakukan komunikasi dengan telepon genggam selain tergantung dari usia, profesi dan daerah asal/ suku orang lebih sering mengabaikan lingkungan sekitarnya, bukan hanya perkara dia hadir di ruang public tersebut, tetapi juga terkait dengan norma ketika berbicara. Banyak halhal pribadi yang seharusnya hanya menjadi milik penelpon dan lawan bicaranya menjadi "tanpa sengaja" tersiar ke ruang public. Untuk memahami kedalaman tentang bagaimana persepsi orang terhadap penggunaan telepon selular di ruang public, perlu dilakukan penelitian lebih lanjut.

Dugaan dari pengamatan sementara itu bahwa orang kemudian ketika melakukan pembicaraan dengan telepon selular, menjadi sulit membedakan mana yang namanya ruang pribadi dan mana ruang public, telepon selular secara instan menjadikan ruang public sebagai ruang pribadi penggunanya.

\section{Daftar Pustaka}

Campbell, Scott W., 2007, Perception Mobile Phone Use in Public Setting: A Cross Cultural Comparasion, Michigan University

Fortunati, L. (2003) The Mobile Phone and Self-presentation, paper presented at the Front Stage/Back Stage: Mobile Communication and the Renegotiation of the Social Sphere Conference, Grimstad, 22-24 June.

Goffman E. 1959, The Presentation of Self in Everyday Life, Garden City, NY, Doubleday
, 1963, Behavior in Public Plac-

es, New York, Free Press

Humphreys, L. (2005) 'Cellphones in Public: Social Interactions in a Wireless Era,' New Media and Society 7(6): 810-833.

Ito, M dan D. Okabe, 2005, Technosocial Situation: Emergent Structuring of Mobile Email Use, in M. Ito, D. Okabe, dan M, Matsuda (eds) Personal, Portabel, Pedestrian: Mobile Phones in Japanese Life, pp. 257-73, Cambrige, MA: MIT Press.

Johnsen, T.E. (2003) 'The Social Context of the Mobile Phone Use of Norwegian Teens,' in J. Katz (ed.), Machines that Become Us: The Social context of Communication Technology, pp. 161-70. New Brunswick, NJ: Transaction Publishers.

Katz, J.E. and M.A. Aakhus (2002) 'Conclusion: Making Meaning of Mobiles - a Theory of Apparatgeist,' in J. Katz and M. Aakhus (eds.), Perpetual Contact: Mobile Communication, Private Talk, Public Performance, pp. 301-18. Cambridge: Cambridge University Press.

Kuswarno, Engkus, 2008, Etnografi Komunikasi: Suatu Pengantar dan Contoh Penelitiannya: Widyaa Padjadjaran, Bandung

Licoppe, C. (2003) 'Two Modes of Maintaining Interpersonal Relations through Telephone: From the Domestic to the Mobile Phone,' in J. Katz (ed.), Machines that Become Us: The Social Context of Communication Technology, pp. 171-86. New Brunswick, NJ: Transaction Publishers

Ling, R. (2002) 'The Social Juxtaposition of Mobile Telephone Conversations in Public Spaces,' paper presented at the Conference on Social and Cultural Impact/Meanings of Mobile Communication, Chunchon, 1315 July.

Love, S. and J. Kewley, J. (2005) 'Does Personality Affect Peoples' Attitude towards Mobile Phone Use in Public Places?' in R. Ling and P. Pedersen (eds.) Mobile Communications: Re-negotiation of the Social Sphere, pp. 273-84. London: Springer. 